\title{
Alquran dan Kepemimpinan Non Muslim di Indonesia
}

\section{Wildan Hidayat}

UIN Sunan Kalijaga Yogyakarta

wildanhidayat29@gmail.com

\begin{abstract}
This paper discusses non-Muslim leadership in the context of modern Indonesia. By using descriptive analytic methods, the writer discusses verses about leadership and links them to the pros and cons about non-Muslim leadership. This study find that some Muslim scholars misused these verses to discredit non-Muslim leadership.
\end{abstract}

Keywords : Controversy, non-Muslim Leader, Islamic State, Indonesia

\begin{abstract}
Abstrak: Makalah ini membahas mengenai kepemimpinan non-Muslim dalam konteks Indonesia modern. Dengan menggunakan metode deskriptf analitik penulis mendiskusikan ayat-ayat tentang kepemimpinan dana mengaitkannya pada kasus prokontra kepemimpinan non-Muslim. Kajian ini menemukan bahwa sebagian sarjana Muslim menyalah gunakan penggunaan ayat-ayat tersebut untuk mendiskreditkan kepemimpinan non-Muslim.
\end{abstract}

Kata kunci: Kontroversi, Pemimpin Non-Muslim, Negara Islam, Indonesia

\section{Pendahuluan}

Sebagaimana diketahui secara umum bahwa Alquran merupakan bukti nyata untuk keabsahan agama Islam. Begitupun Hadis menjadi seperangkat interpreter atas teks suci Alquran itu sendiri. Alquran secara pribadi dalam ranah realitas sosial telah berkembang maknanya. Dalam memaknai pemimpin sebagai pribadi yang memiliki peran sangat penting di dalam sebuah kelompok, baik kelompok sedikit ataupun banyak, lantas kehadiran serta laju arah kelompok itu kemudian akan bertumpu pada bagaimana seorang pemimpin memimpin kelompok tersebut. Bisa jadi dalam perjalanan kepemimpinannya sampai ke arah sejahtera dan makmur atau justru mengarahkan kelompok kepada jalan kehancuran. Oleh karenanya selektif dan berhati-hati dalam memilih seorang pemimpin menjadi kewajiban bagi individu masing-masing jika 
kemakmuran dan kesejahteraaan bersama yang diharapkan. Islam yang tampil menjadi anutan yang "raḥmatan li al- 'âlamìn" dalam hal ini dengan Alquran yang menjadi pangkal dasar dan paling utama dalam syari'at, kemudian Nabi Muhammad SAW diutus kedunia untuk menjadi rahmat untuk semesta alam.

Kehendak Alquran ialah dapat tercapainya suatu kehidupan manusia bermoral yang menghargai nilai kemanusian secara universal. Oleh karena itu, Islam memiliki syari'at guna membangun humanisme universal, seperti kemaslahatan, keadilan, kesetaraan dan kebijaksanaan. ${ }^{1}$ Hal ini yang lantas menjadi prinsip pokok dalam berbagai macam permasalahan yang sedang dihadapi (Șāliḥ likulli zamān wa al-makān). Dalam substansi yang serupa juga Islam senantiasa datang sebagai sesuatu yang adil, damai, egaliter, dan demokratis. Selain itu, terkait hal tersebut Islam juga menilai bahwa sebagai sesama makhluk ciptaan Tuhan manusia adalah sama, sederajat dan sejajar. Jadi, skema keagamaan yang mengandung unsur diskriminatif dalam segala dimensinya baik ras, agama, gender dan lainnya taklayak dengan apa yang dicitakan agama Islam dan kemudian meski ditolak. Prinsip-prinsip hak asasi manusia ini merpakan ruh bagi aktivitas umat mansia. ${ }^{2}$ Hal-hal yang menggambarkan prinsip-prinsip dasar Islam untuk memayungi hak-hak asasi manusia diatas sebenarnya memang sudah menjadi komitmen seluruh umat Islam. Akan tetapi, masalahnya tidak sesederhana ketika mereka memasukkan persoalan-persoalan khusus, seperti perbedaan agama. Dalam hal kepemimpinan yang didalamnya diperlukan pengambilan keputusan yang mengikat dan menyangkut masyarakat luas.

Seolah sudah menjadi rahasia umum memang, yaitu Indonesia negara mayoritas berpenduduk muslim, dengan jumlah paling banyak di dunia. Bahkan jauh melebihi negara-negara Islam Timur yang menjadi tempat kelahiran Islam sendiri seperti Mesir, Iran, Al-Jazair, Pakistan, Banglades, Maroko, bahkan Arab Saudi. ${ }^{3}$ Tidak sama dengan Negara yang menggunakan simbol Islam sehingga menamakan Negara agama, sehinggapun perundang-undangan yang ada harus menggunakan tata aturan agama

\footnotetext{
${ }^{1}$ Akhmad Haries, "Kepemimpinan Perempuan (Analisis Penafsiran Ulama Terhadap Surah alNisā' (4): 34 dan Hadis Nabi Muhammad SAW yang bersumber dari Abü Bakrah)", jurnal Mazahib VI, 1 (2009), h. 25. Lihat pula Ibn Qayyīm al-Jauziyyah, A'lām al-Muwaqqī'in Rabb al- 'Ālaminn, (Qāhirah: Maktabah al-Kulliyyah al-Aẓhāriyyah, t.t.), 78.

${ }^{2}$ Akhmad Haries, "Kepemimpinan Perempuan (Analisis Penafsiran Ulama Terhadap Surah alNisā' (4): 34 dan Hadis Nabi Muhammad SAW yang bersumber dari Abū Bakrah)", 26.

${ }^{3}$ Ibnu Mujar Syarif, Presiden Non Muslim di Negara Muslim: Tinjauan dari Perspektif Politik Islam dan Revolusinya dalam Konteks Indonesia (Jakarta: Pustaka Sinar Harapan, 2006), 4-5.
} 
Islam. Sementara Indonesia bukanlah negara Islam, karena masyarakatnya beragam dalam ras, suku, agama dan keyakinan, bahkan dalam UUD 1945 tidak ada pasal dan ayat yang menyebutkan secara gamblang tentang keislaman negara Indonesia. ${ }^{4}$ Oleh karena Indonesia yang penduduknya mayoritas Islam, lalu muncul kesimpang siuran reaksi masyarakat dalam menanggapi isu kepemimpinan non-Muslim, khususnya umat Islam Indonesia kebanyakan akan beranggapan bahwa semacam ini seolah tidak sesuai dengan ajaran Alquran dan Sunah sebagai pedoman umat Islam untuk berbangsa dan bernegara.

Jika dilihat melalui kacamata teologis, memang pembahasan mengenai pemimpin dan kepemimpinan non-Muslim adalah suatu pembahasan cukup kontroversial. Kontroversi dalam hal terjadi karena dalam Alquran yang notabene sebagai rujukan pertama dalam hukum Islam, di samping ditemukan dalil-dalil yang melarang umat Islam memilih non-Muslim sebagai pemimpinnya, ditemukan juga dalil-dalil lain yang megarah pada pembolehan dalam memilih pemimpin non-Muslim. Lantas berbedanya ulama yang berperan sebagai interpretator dalam menafsirkan dalil-dalil tersebut melahirkan pendapat yang variatif.

Tidak cukup sejatinya jika sampai pada tahap ini, sebagai Muslim tentunya perlu mentas dari ke-stagnan-an dalam berdebat tentangkebolehan atau ketidak bolehan pemimpin non-Muslim, justru seabagai muslim yang cendekia dan visioner diperlukan sikap berani untuk lebih menyiapkan pemimpin yang ideal dan cakap untuk masyarakat yang mayoritas penduduknya muslim seperti khususnya dalam konteks Indoensia yang mayoritas masyarakatnya muslim.

\section{Definisi dan Tipologi non-Muslim}

Non-Muslim dapat diartikan sebagai tidak Islam atau dengan kata lain selain dari orang Islam, meski itu orang Nasrani, Yahudi ataupun pemeluk agama lain. Dalam masyarakat umum, dapat diklasifikasikan tiga golongan yang disebut non-muslim, antara lain:

Pertama, Murtad (keluar dari Islam). Secara harfiah, terma murtad dapat diartikan kepada seseorang yang telah berbalik, dan keluar. Dalam prinsip Islam, murtad

\footnotetext{
${ }^{4}$ Munawir Syadzali, Islam: Realitas Baru dan Orientasi Masa Depan Bangsa (Jakarta: UI Press, 1993), 80.
} 
bermakna berbalik dari Islam ke agama yang lain, atau sama sekali tidak memeluk agama. ${ }^{5}$ Murtad dapat terjadi karena seseorang melakukan sesuatu yang jelas keharamannya, namun tetap saja mengerjakannya. Biasanya perbuatan tersebut dilakukan dengan sengaja, baik dengan tujuan merendahkan agama Islam itu sendiri atau sebab keras kepala.

Kedua, Ahli Kitab. Para ulama mendefinisikan Ahli Kitab sebagai orang-orang yang telah memiliki dan meyakini kitab suci sebelum Alquran. ${ }^{6}$ Istilah ini biasanya diobjekkan kepada para pemeluk agama yahudi dan nasrani (kristen), ${ }^{7}$ Begitu juga maksud dari Alquran dan Hadis. Akan tetapi sebagian ulama lain juga memperluas pembahasan makna Ahlul Kitab, sehinggga maknanya tidak hanya bagi kelompokkelompok tersebut, namun juga perayaan lainnya, seperti Majūsī dan Șābi 'īn. ${ }^{8}$

Ketiga, Kafir. Secara makna terminologi kafir adalah orang yang menentang, menolak, terhadap kebenaran dari Allah SWT, yang sudah tersamaikan oleh Rasul-Nya atau secara singkat kafir adalah kebalikan dari iman. ${ }^{9}$

\section{Negara Muslim dengan Pemimpin non-Muslim}

Di era modern sekarang ini, kontroversi menyangkut hal-hal yang memungkinkan bagi seorang non-Muslim untuk menjadi pemimpin, misalnya menjadi presiden atau gubernur di negara atau wilayah yangmayoritas penduduknya beragama Islam masih terus berlangsung bahkan hingga detik ini. Sebelum kejadian Basuki Tjahaja Purnama (Ahok) menistakan agama yang baru-baru ini melambung, pada tahun 2012 silam juga sempat terjadi kasus serupa yang bahkan Ahok sudah ikut terseret kedalamnya. Bermula dari ceramah yang disampaikan oleh Rhoma Irama tentang kriteria pemimpin dalam Pemilukada DKI Jakarta tahun 2012, ia sempat menjadikan Alquran tepatnya surat alNisā': 104 yang mengandung larangan untuk memlih pemimpin non-Muslim. Menurutnya, orang Islam yang memilih pemimpin di luar Islam akan menjadikan

\footnotetext{
${ }^{5}$ Nasaruddin Umar, Deradikalisasi Pemahaman Alquran dan Hadis (Jakarta: PT Elex Media Komputindo, 2014), 146.

${ }^{6}$ Nasaruddin Umar, Deradikalisasi Pemahaman Alquran dan Hadis, 176.

${ }^{7}$ Seperti pendapat Quraish Shihab dalam bukunya Wawasan Alquran, dijelaskan mengenai non Muslim seperti Yahudi dan Nasrani, dua kelompok masyarakat yang minimal disepakati oleh seluruh ulama sebagai ahl al-kitāb. M. Quraish Shihab, Wawasan Alquran, (Tafsir Tematik atas Berbagai Persoalan Umat), Cet. 1 (Bandung: PT Mizan Pustaka, 2013), 458.

${ }^{8}$ Cyril Gkasse, Ensiklopedi Islam, Cet. 2, (Jakarta: PT Raja Grafindo Persada, 1997), 15.

${ }^{9}$ Harifuddin Cawidu, Konsep Kufur Dalam Alquran; Suatu Kajian Teologis Dengan Pendekatan Tafsir Tematik (Jakarta: Bulan Bintang, 1991), 7.
} 
mereka sebagai musuh Allah. Jika melihat relevansi dari pernyataan Rhoma Irama tersebut, tentu konotasinya akan mengarah kepada larangan untuk tidak memilih Jokowi dan Ahok sebagai Gubernur dan Wakil Gubernur DKI Jakarta kala itu. ${ }^{10}$ Kemudian disusul dengan kasus yang terjadi di Lenteng Agung, Jakarta Selatan, dengan diangkatnya Susan Jasmine Zulkifli sebagai Lurah. Hal-hal serupa diatas yang lantas meramaikan argumen menolak non-Muslim menjadi pemimpin dalam Negara yang mayoritas masyarakatnya Muslim.

Jika dilihat melalui kacamata yang lebih luas dan global, sebenarnya setiap negara muslim memiliki kebijakan dan aturan yang mungkin berbeda dengan negara muslim lain. Beberapa Negara yang penduduknya banyak masyarakat Muslim, seperti Yordania, Tunisia, Malaysia, Suriah, Pakistan Banglades Mesir, Iran, dan al-Jazair. Semuanya mengharuskan pemimpin yang seagama. ${ }^{11}$ Sebabnya, tidak bisa menjadi pemimpin di Negara-negara tersebut. Sedikit sekali dari Negara yang mayoritas penduduknya Muslim yang memperbolehkan atau juga pernah dipimpin oleh pemimpin non-Muslim. Dan sejauh saat ini, yang bisa dijadikan sebagai contoh ada 3 Negara, sebagai berikut:

Pertama, Libanon. Dengan presentase sebanyak $75 \%$ dari penduduknya yang memeluk agama Islam, yang memimpin negara tersebut adalah pemimpin yang mememluk agama Kristen sejak 1943. Hal yang menjadi sebab Libanon dipimpin oleh non-Muslim adalah karena pada tahun 1943 telah disetujuinya Fakta Nasional (al-Mis̄āq al-Wațan $\vec{\imath}$ berisinya tentnag ketetapan bahwa presiden Libanon harus berasal dari Kristen Maronite, Perdana Mneteri berasal dari Muslim Sunny, Juru Bicara Parlemen Muslim Syi'ah, Menteri Pertahanan Muslim Druze, dan Menteri Luar Negeri Kristen Ortodok Yunani. ${ }^{12}$ Sebab hal itu tetap diyakini dan dilakukan, jadi orang yang menduduki kursi kepresidenan Libanon hanya seorang yang menganut kepercayaan Kristen Maronite dengan Michel Aoun sebagai Presiden saat ini.

Kedua, Nigeria. Hampir serupa dengan Libanon, dengan mayoritas penduduknya yang memeluk agama Islam (76\%), presiden Nigeria pernah berasal dari penganut agama Kristen, yakni Olusegun Mathew Okikiọla Arẹmu Ọbasanjọ (Obasanjo).

\footnotetext{
${ }^{10} \mathrm{Abu}$, "Terus Ungkap Asal-Usul Jokowi-Ahok, " http://www.jpnn.com/read/2012/08/14/136783/Terus-Ungkap-Asal-Usul-Jokowi-Ahok-, diakses Selasa, 24 Oktober 2018, 11:22 WIB.

${ }^{11}$ John L. Esposito, Islam dan Politik, terj. Joesoef Sou'ybdari Islam and Politics, Cet. 1 (Jakarta: Bulan Bintang, 1990), 132.

${ }^{12}$ Pakta Nasional yang ditetapkan pada tahun 1943 dan disetujui perimbangan penduduk Libanon yang terdiri dari: Kristen 55 persen dan Islam 45 persen, lihat Tempo, 8 Oktober 1983, h. 15.
} 
Bedanya, Nigeria tidak menerapkan Pakta Nasional seperti Libanon yang mengatur bahwa seorang kepala negara haruslah Kristen. Bahkan merupakan sebuah pencapaian karir kepemimpinan yang luar biasa bagi seorang Obasanjo, sekalipun Bergama Kristen, dan ia berhasil menjadi presiden Nigeria yang mayoritas penduduknya adalam Muslim, lamanya 3 periode, yakni periode 1976-1979, periode 1999-2004, dan periode 20042007. Saat periode ketiga Obasanjo dipilih masyarakat kembali menjadi pemimpin Nigeria dengan mengalahkan Muhammad Buhari. Obasanjo adalah orang terunggul dalam pemilihan pemilu presiden Nigeria tahun 2004, mendapatkan 62\% suara. Presiden setelahnya juga merupakan seorang non-Muslim yang kembali memenangkan pemilu Nigeria yaitu Goodluck Jonathan dengan masa jabatan 2007-2010.

Ketiga, Senegal. Dibandingkan dengan Libanon dan Nigeria, mayoritas Muslim di Senegal lebih banyak bahkan, sudah menyentuh angka $91 \%$, tentu menjadi hal yang luar biasa jika Negara dengan penduduknya hampir semua beragama Islam justru pernah dipimpin oleh seorang non-Muslim. Seorang Kristen Katolik yang pernah menduduki kursi tertinggi di Senegal adalah Léopold Sédar Senghor dengan masa jabatan yang cukup lama yakni dari tahun 1960 sampai dengan tahun 1980.

\section{Pro dan Kontra Kepemimpinan non-Muslim}

Isu kepemimpinan non-muslim ini, ulama tidak sependapat dalam menghadapinya. Pendapat mereka dapat dipetakan kedalam dua kelompok, yakni kelompok yang menerima pemimpin non-Muslim dan kelompok yang tidak meneriman pemimpin non-Muslim. Sejauh ini pendapat dari kelompok yang menolak terhadap pemimpin non-Muslim memang lebih banyak dijadikan pegangan dan jawaban atas kegelisahan problematik kebimbangan antara boleh dan tidaknya memilih non-Muslim sebagai pemimpin. Tanpa menafikan hal diatas, bukan berarti kelompok yang menerima non-Muslim sebagai pemimpin hanya menjadikan dalil-dalil serta teks-teks suci keagamaan sebagai pembenaran asumsi mereka.

\section{Kelompok Pertama: Menolak Pemimpin non-Muslim}

Dari kelompok yang menolak kepemimpinan non-Muslim ini mayoritas dari mereka adalah 'ulama-'ulama klasik yang mendasarkan pendapatnya kepada Alquran, yakni surat Alī-'imrān ayat 28: 
“Janganlah orang-orang mukmin mengambil orang-orang kafir menjadi wali dengan meninggalkan orang-orang mukmin. barang siapa berbuat demikian, niscaya lepaslah ia dari pertolongan Allah, kecuali karena (siasat) memelihara diri dari sesuatu yang ditakuti dari mereka. dan Allah memperingatkan kamu terhadap diri (siksa)-Nya. dan hanya kepada Allah kembali (mu)", 13

Tidak hanya ayat ini, beberapa ayat lain juga yang senada dan juga tak jarang digunakan sebagai dasar atas penolakan terhadap pemimpin non-Muslim dalam Islam. Diantaranya yaitu: QS. al-Mā'idah: 51, QS. al-Mumtaḥanah: 1, QS. Āli -'Imrān: 100 dan 118, QS. al-Mujādalah: 22, QS. al-Nisā’: 144, QS, al-Anfāl: 73, QS. al-Taubah: 71, dan QS. al-Nisā': 141. Kendati ada beberapa ayat yang redaksinya sedikit berbeda dari kebanyakan ayat lain, namun esensi ayat tersebut mengacu kepada ini sebuah permasalahan senada, ialah pemeluk agama Islam tidak diperbolehkan untuk memilih pemimpin yang bukan Islam.

Diantara Para ilmuan Islam ('ulama) yang termasuk kedalam kelompok yang menolak pemimpin dari luar Islam, antara lain:

\section{al-Jașșāṣ}

Abū Bakr Aḥmad Ibn 'Alī al-Rāzī al-Jașșāṣ lahir 305 di Rayyi, Iraq. ${ }^{14}$ AL-Jașṣāṣ pergi ke Bagdad pad tahun $325 \mathrm{H}$ untuk memperdalam keilmuan. Orang-orang mengenalnya adalah seorang yang menganut mazhab Hanafi dan memiliki sifat zahid dan wara. Dia hidup pada masa perkembangan ilmu pengetahuan dan 'ulama yang ahli dalam di banyak ilmu pengetahuan.

al-Jașșāṣ dikenal sebagai imam fikih Hanafi pada abad 14 M, kitabnya yang berjudul Ahkām al-Qur'an dinilai sebagai karya paling penting di samping karyakaryanya yang lain, terutama bagi pengkut mazhab Hanafi.

Dalam kitab Ahkām al-Qur'ān, al-Jașāṣ memberikan catatan terhadap ayat-ayat kepemimpinan non-Muslim diatas sebagai berikut :

\footnotetext{
${ }^{13}$ Terjemahan dari QS. Āli 'Imrān: 28.

${ }^{14}$ Ṣafwat Musțafa Khalīlupethes, Al-Imām Abū Bakr al-Rāzī al-Jaṣāṣ wa Manhājuhu fĩ al-Tafsīr (Qāhirah: Dār al-Salām), 54.
} 


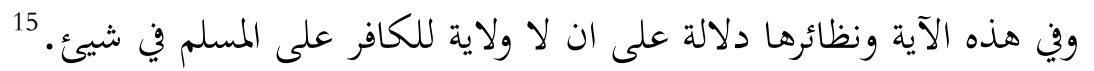

"Dalam ayat ini (ali-Imran ayat 28) dan ayat-ayat lain yang senada dengannya ada petunjuk bahwa dalam hal apapun orang kafir tidak boleh berkuasa atas (umat) Islam”.

Dari keyakinannya, al-Jașșāṣ bukan saja tidak memperbolehkan pemeluk Islam menjadikan non-Muslim sebagai pemimpin, namun juga tidak dibolehkannya umat selain Islam mengurusi persoalan umat Islam, walaupun ada hubungan darah. Sebabnya, seorang laki-laki non-Muslim, meurutnya, tidak mempunyai hak untuk mengurus pernikahan putra kandungnya yang Muslim sebab alasan berlainan agama. ${ }^{16}$

Nama kitab Aḥkām al-Qur'ān tidak saja milik al-Jașșāṣ, Namun ada yang lain, bahkan di dalamnya juga terdapat pandangan yang serupa tentang penolakan terhadap pemimpin non-Muslim. Senada dengan al-Jașāṣseperti, Ibn 'Arabī yang memberikan pandangan didalam kitab Ahkām al-Qur'ān karyanya, bahwa ayat-ayat tersebut berisi ketentun seorang mukmin untuk tidak memilih pemimpin non-Islam, atau juga untuk menjadi sekutunya, dan juga tidak untuk menjadi teman sebagai teman yang terpercaya. $^{17}$

\section{Sayyid Quț}

Sayyid Quṭb merupakan salah seorang mufassir yang mendunia dengan karyakaryanya, dan karya yang dianggap sangat penting adalah kitab $F \bar{\imath}$ Zilāl al-Qur' $\bar{a} n .{ }^{18}$ Ia juga merupakan seorang tokoh besar Ikhwanul Muslimin pada masanya.

Dalam kaitannya dengan pembahasan kepemimpinan non-Muslim, Sayyid Quṭb adalah golongan yang sangat tegas menolak pemimpin non-Muslim. Bahkan Quṭb memiliki gagasan bahwa hanya memberi bantuan atau bersahabat dengan non-Muslim tidak diperbolehkan, terutama dengan pemeluk agama Yahudi dan Nasrani, tidak diperkenankan untuk melakukan mennolong atau berteman.

\footnotetext{
${ }^{15}$ Abū Bakr Aḥmad Ibn 'Alī al-Rāzī al-Jașāṣ, Aḥkām Al-Qur'ān, jilid 2 (Qāhirah: Syirkah alMaktabah wa Maṭba'ah Abd al-Raḥmān Muhammad, t.t.), 290.

${ }^{16} \mathrm{Abū}$ Bakr Aḥmad Ibn 'Alī al-Rāzī al-Jașāṣ, Ahkām Al-Qur'ān, 290.

${ }^{17} \mathrm{Abū}$ Bakr Muḥammad Ibn 'Abdillāh Ibn 'Arabī, Aḥkām al-Qur'ān, jilid 2 (Bairūt-Libanon : Dār al-Quṭb al-'Ilmiyyah, 1988), 138-139.

${ }^{18}$ Muhammad Ishom, "Pemikiran Sayyid Quṭb dalam Referensi Gerakan Islam Politik", al Qisthas: Jurnal Hukum dan Politik 9, (2018), 6.
} 
Pemeluk agama Islam, tegasnya, dianjurkan untuk bersikap toleransi terhadap ahli kitab dan non-Muslim yang lain, bersikap baik, tidak memihak, dan damai. Akan tetapi tidak boleh memberikan kepercayaan untuk urusan orang Islam. Karena memberi loyalitas itu adalah sesuatu yang sangat berbeda dengan toleransi. Toleransi dapat berupa muamalah yang baik (Mu'āmalah bi al-Husnā') terhadap non-Muslim. Islam mengajarkan umatnya untuk memberikan loylitasnya hanya untuk Allah, Rasul-Nya, dan kelompok Islam saja. Seperti apa yang dituliskan dalam kitab F̄̄ Zilāl al-Qur'ān berikut :

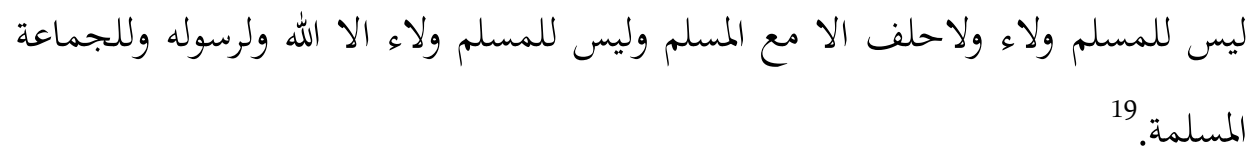

"Seorang Muslim tidak boleh memberikan loyalitas dan memadu janji setia kecuali dengan sesame Muslim.Seorang Muslim tidak boleh memberikan loyalitasnya kecuali kepada Allah, Rasul-Nya, dan kelompok Muslim”.

Sayyid Quṭb dengan tegas menolak keagama yang masih bekerjasama dengan ahli sekuler, yang mendukung adanya kerjasama dan menolong antar ahli kitab. Sayyid Quṭb beralasn karena tidak mengerti Islam dan Alquran. Sebab itu menurutnya, orang semacam demikian harus dilarang bermu'amalah dengan ahli kitab, seperti tertulis dalam QS. al-Mā'idah: 51 (dan ayat-ayat yang hampir sama dengan itu), bukan saja dimaksudkan kepada orang mukmin di masa Nabi SAW yang ada di Madiah zaman dahulu saja. Namun khitab ayatnya juga berlaku untuk semua manusia di muka bumi.

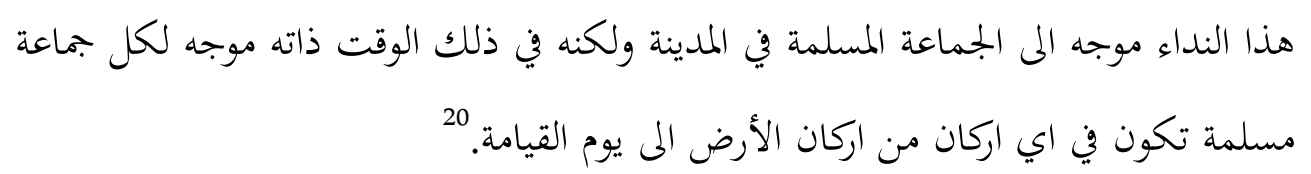

Seruan (al-Mā'idah: 51) ini (semula memang) ditujukan kepada umat Islam di Madinah.Tapi sejak saat itu juga (seruan ayat tersebut) juga ditujukan kepada segenap umat Islam, (kapan) dan di belahan dunia manapun hingga hari kiamat kelak.

Melalui penalaran analogis terhadap ungkapan Sayyid Quṭb di atas, bahwa dengan semangat belajar sebagai pemeluk agama Islam, di mana pun dana kapan pun berada,

\footnotetext{
${ }^{19}$ Sayyid Quṭb, Fī Zilāl al-Qur'ān, Jilid 2 (Bairūt-Libanon : Dār Ihyyā al-Turāṡ al-‘Arabī, 1967), 198-199.

${ }^{20}$ Sayyid Quṭb, F̄̄ Zilāl al-Qur'ān, Jilid 2 (Bāirūt-Libanon : Dār Iḥyā al-Turās̀ al-‘Arabī, 1967), 198-199.
} 
tetap tidak diperbolehkan tolong-menolong dan bekerja sama dengan orang pemeluk agama lain sampai hari akhir nanti, jadi pandangan ini menuju pada tidak boleh dan haram hukumnya untuk memilih pemimpin selain Islam, kapanpun dan dimanapun.

Selain tokoh-tokoh yang disebutkan diatas, terdapat beberapa tokoh Muslim lainnya yang sependapat dengan penolakan terhadap kepemimpinan non-Muslim. Seperti halnya Ibn Kāsisir, al-Ṭabārī, al-Alūs̄̄, Ṭabā'țabā'i, Ḥasan al-Bannā, dan beberapa tokoh lainnya.

Kelompok Kedua: Mendukung Pemimpin non-Muslim

Terdapat beberapa intelektual Muslim yang mencoba memberi penawaran ijtihad politik baru untuk bisa memilih pemimpin selain Islam. Yang termasuk kedalam kelompok ini, diantaranya adalah :

\section{'Abdullah Ahmad al-Na'ìm}

Seorang pemikir Islam kontemporer asal Sudan, al-Na'īm menawarkan tiga konsep pemikiran diantaranya adalah Reformasi Syari'ah. Istilah Reformasi Syari'ah digunakan untuk menyebut Syari'at Islam. Menurutnya, umat Islam dilarang menerapkan aturan-aturan agama Islam dalam bernegara, dan sebaliknya, sebagai kopinya pluralistik, syari'ah harus sanggup mengakomodir kebutuhan-kebutuhan umat minoritas. $^{21}$

Al- Na'īm menyatakn, pendapat yang menolak pemimin non muslim dapat dianggap benar. Alasannya sebab semasa awal pembentukan syariat tidak ditemukannya konsep-konsep hak asasi manusia unibversal di dunia. Sejak abad ke-7 hingga abad ke20, menurutnya, lumrah di seluruh dunia untuk menentukan status hak-hak orang dan agama. Dengan kata lain, diskriminasi atas dasar agama adalah normaseluruh dunia pada waktu itu. ${ }^{22}$ Oleh sebab demikian, fikih klasik yang menolak pemimpin nonmuslim dapat dibenarkan dengan otoritas historisnya. ${ }^{23}$

Pandangan al-Na'īm terhadap pemikiran politik Islam klasik dan menolak pemimpin sejarah, menurutnya, meskipun dijelaskan dari sumber wahyu Alquran dan

${ }^{21}$ Zuly Qodir, Pembaharuan Pemikiran Islam (Yogyakarta: Pustaka Pelajar, 2006), 13.

22، Abdullāh Ahmad al-Na'îm, Toward an Islamic Reformation: Civil Liberties Human Rights and International Law, terj. Ahmad Suaedy dan Amiruddin Arrany, Dekonstruksi Syariah, (Yogyakarta : LKIS, 1994), 282.

${ }^{23}$ 'Abdullāh Ahmad al-Na'īm, Toward an Islamic Reformation: Civil Liberties Human Rights and International Law, 282. 
al-Sunnah, sungguh bukanlah wahyu, jadi hanya produk penafsiran manusia atas sumber-sumber tersebut, yang hal itu memiliki perbedaan zaman.

Hemat penulis, ayat-ayat Alquran banyakdengan pemaknaan semua agama itu sata, maka perlu ditonjolkan adalah ayat-ayat makiyah yang menjelaskan tentang kesamaan secara umum bagi seluruh manusia, dengan tidak melihat kepada kepercayaan yang dianutnya. Seperti yang tergambar dalam surat al-Hujurāt ayat 13 :

"Hai manusia, Sesungguhnya Kami menciptakan kamu dari seorang lakilaki dan seorang perempuan dan menjadikan kamu berbangsa - bangsa dan bersuku-suku supaya kamu saling kenal-mengenal. Sesungguhnya orang yang paling mulia diantara kamu disisi Allah ialah orang yang paling taqwa diantara kamu. "24

Pesan yang hendak disampaikan al-Na'īm dalam hal ini adalah perlunya umat Islam untuk mengalihkan pandangan diskriminatif terhadap non-Muslim kepada pandangan yang lebih harmonis, "yaitu suatu prinsip timbal balik dalam menghargai keyakinan orang lain. Dengan melaksanakan prinsip itu, seseorang bisa bersikap yang tidak sama keyakinan dengannya, sama seperti sikap yang diinginkannya dari orang lain untuk dirinya sendiri." 25

Selain dari pendapat al-Na'īm di atas, beberapa sarjana Muslim lain seperti Maḥmūd Muḥammad Ṭāha dan Asghar Ali Enginer juga menempatkan dirinya pada posisi yang sama dengan al-Na'īm, yakni pendapat yang mengarah pada pembolehan non-Muslim menjadi pemimpin di Negara mayoritas Muslim.

\section{Nalar Islam Indonesia: Tinjauan Problematis Relevansi Teks dan Konteks}

Hukum adalah produk dinamaika dalam sosio-kultural-politik. Sebab itu ia bersifaat dinamis. Hal itu berbeda dengan konteks sosial dan kultural saat ini, utamanya setelah diperkenalkan demokrasi tidak mengizinkan untuk menekan hak-hak individu kelompok minoritas di pelataran luas teras mainstream. Saat ini perlu adanaya prinsip: setiap orang memiliki hak yang sama di depan hukum. Menolak prinsip ini berarti kita telah mendukung ketidakadilan. Padahal, ketidakadilan sesungguhnya merupakan musuh utama hukum Islam. Mengutip Ibn al-Qayyīm, dikatakan Noryamin menyatakan,

\footnotetext{
${ }^{24}$ Terjemah dari QS. al-Ḥujurāt: 13

${ }^{25}$ Abdullāh Aḥmad al-Na'̄̄m, Toward an Islamic Reformation: Civil Liberties Human Rights and International Law, 268.
} 
"bukanlah syari'at Islam jika wacana tafsir agama teks suci bersikap diskriminatif terhadap satu kelompok sosial tertentu. Bila pendapat ini diterima, maka menolak hak non-Muslim untuk menjadi presiden sama artinya dengan membuka front permusuhan terhadap Islam yang mengajarkan keadilan dan kesetaraan. Bila tidak ingin diklaim sebagai para penentang Islam, maka segala bentuk hukum yang beraura diskriminatif, sekalipun diyakini banyak orang sebagai kebenaran, harus segera dianulir, atau minimal, perlu dikaji ulang." 26

Menurut M. Quraish Shihab, memilih pemimpin non-Muslim tidak ada larangannya, jika itu memang bermanfaat untuk orang banyak. Bahkan, orang yang menunjukkan jalan kepada nabi Muhammad SAW ketika hijrah ke Madinah adalah non-Muslim. Memang ada ayat yang menyatakan larangan seperti dalam surat Āli'Imrān ayat 118 di atas. Namun, larangan tersebut berkaitang dengan larangan sebelumnya. Jadi, ahli tafsir bernama Rasyid Rị̣ā menulis saat memaknai ayat di atas, yakni: "Kemudahan yang diajarkan Alquran inilah yang dipraktikkan oleh 'Umar ibn Khatțāb dengan menyerahkan kepemimpinan perkantoran kepada orang-orang Romawi (yang non-Muslim ketika saat itu). Kebijakan serupa diambil oleh kedua khalifah sesudahnya yaitu 'Uṡman ibn 'Affān dan Āli ibn Abī Țālib. Demikian juga yang diterapkan oleh Dinasti Abbasiyah dan penguasa-penguasa muslim sesudah mereka. Yakni menyerahkan kepemimpinan tugas negara kepada orang Yahudi, Nasrani, Budha.Kerajaan Utsmaniyyah pun demikian, bahkan duta-duta besar perwakilanperwakilannya di luar negeri mayoritas dipegang oleh orang Nasrani."27

Aroma pembahasan tentang kepemimpinan dalam Islam memang kental dengan kajian hukum Islam atau syari'at, hal ini tidak dapat dipisahkan karena memang syari'at lah yang menaungi substansi hukum dan aturan-aturan kepemimpinan itu sendiri. Dari penjelasan di atas bisa ditemukan suatu kesimpulan dari pertanyaan tentang boleh tidaknya menjadikan seorang non-Muslim sebagai pemimpin di suatu negara atau wilayah yang mayoritas penduduknya memeluk Islam. Merujuk pada pandangan Quraish Shihab bahwa larangan memilih non-Muslim tidak mutlak adanya, tidak

\footnotetext{
${ }^{26}$ Noryamin Aini, "Dasar Legitimasi Sosiologis Gagasan Perubahan Undang-Undang No. 1 Tahun 1974 Dalam Konteks Perubahan Sosial”, Jurnal Syariah Jurnal Ilmu Hukum 1, 7 (2007), 32-37.

${ }^{27}$ M. Quraish Shihab, Menjawab 1001 Soal Keislaman Yang Patut Anda Ketahui (Jakarta: Lentera Hati, 2008), 884-885.
} 
mutlaknya larangan tersebut karena larangan ini dilakukan jika sudah terjadi malapetaka (bencana) yang tidak dapat diielakkan.

Jika dihadapkan dengan konteks Indonesia saat ini yang notabene sebagai negara yang multidimensi dalil-dalil agama untuk menjadi aturan hidup, sehingga hukum digunakan untuk menyatukan orang Islam, baik di tingkat nasional atau internasional.

Pendapat Quraish di atas, menurut pertimbangan penulis, sangat perlu untuk direnungi oleh golongan Muslim Indonesia yang senantiasa menderukan penolakanpenolakan tanpa ada solusi nyata yang mereka temukan. Sikap yang perlu ditampakkan adalah perlunya move on dari kegelisahan dan perdebatan tentang boleh atau tidaknya pemimpin non-Muslim. Sebagai Muslim justru harus lebih siap dan cermat untuk menyiapkan sosok pemimpin Islam yang kompeten dan benar-benar sesuai dengan citacoita masyarakat, tidak hanya umat Muslim saja tentunya, terlebih jika konteksnya Indonesia. Dengan lahirnya pemimpin Muslim yang cakap dan kompeten ini kemudian akan dapat menjadi peredam problematika dan perdebatan yang mucul belakangan ini, serta dapat memupus kegelisahan atas penolakan ini.

Pemimpin merupakan ruh dari sebuah negara yang dipimpin, ianya menempati posisi yang sangat penting dalam Islam. Karena ditangannya tergenggam kebijakankebijakan dan kebijakan yang berurusan dengan kepentingan orang banyak terkait berbagai macam aspek mulai dari sosial, kesehatan, perekonomian, kesehatan dan kebijakan publik lainnya.Terkait hal ini pula Islam memberikan gambaran dan solusi konkrit terkait kemaslahatan dalam memilah dan memilih pemimpin.

Selain daripada 'ulama yang menekankan pengharaman mutlak terhadap pemimpin non-Muslim, peniliti justru menganggap tawaran al-Māwardī dalam alAḥkām al-Sulțān̄yah miliknya lebih dapat diterima secara ilmiah dan terkesan moderat. Terlebih jika hal ini dihadapkan dengan konteks Indonesia yang masyarakatnya plural. al-Māwardī memberikan penjelasan secara rinci terhadap status "jabatan" yang dimaksudkan dalam konteks kepemimpinan.

$$
\begin{aligned}
& 28 \\
& \text {. . . ويجوز أن يكون هذا الوزير من أهل الذمة وإن لم يجز أن يكون وزير التفويض منهم. } \\
& \text { “. . Posisi pejabat ini (tanfižleksekutif) boleh diisi oleh zimmī (non- } \\
& \text { Muslim yang siap hidup bersama muslim). Namun untuk posisi pejabat }
\end{aligned}
$$

${ }^{28}$ Abū al-Ḥasan al-Māwardī, al-Aḥkām al-Sulțānīyah wa al-Wilāyāt al-Dīnīyah, (Bairūt: Dār alFikr, 1996), 27. 
tafwìd yakni pejabat dengan otoritas regulasi, legislasi, yudikasi dan otoritas semacamnya tidak boleh diisi oleh kalangan mereka."

Pernyataan al-Māwardī diatas menguraikan secara rinci bahwa kekuasaan dibagi menjadi dua macam yakni tafwīẹ dan tanfiž. Bagian pertama mempunyai batasan kerja penanganan hukum dana analisa pelbagai kezaliman, mengatur dan menggerakkan tentara dengan strategi perangnya, mengatur anggaran, regulasi dan legislasi. Untuk kuasa tafwị̀ ini al-Māwardī mensyaratkan harus Islam, pemahaman hukum agama yang cakap dan merdeka.Sedangkan kekuasaan tanfï (eksekutif) mengampu pelaksanaan dari peraturan-peraturan yang sebelumnya telah dirumuskan oleh tafwīẹ. Dalam hal ini tidak diharuskan Islam, paham dengan hukum agama dan merdeka.

Hal ini yang lantas relevan dengan konteks Indonesia, untuk memilih pejabat eksekutif seperti Gubernur, Bupati, Walikota, Camat, Lurah atau ketua RT/RW dari kalangan non-Muslim sangat dimungkinkan. Pasalnya mereka ini tergolong tanfiz yang bertugas sebagai pelaksana undang-undang dasar dan undang-undang turunan lainnya. Dalam konteks kebhinekaan pula pemimpin non-Muslim tidak dapat membuat aturan semaunya, apalagi hanya untuk mendukung kekufurannya karena ia harus tunduk terhadap undang-undang dasar dan undang-undang turunan lainnya. Selain itu kepemimpinan Indonesia pun sudah terkonsep pada tiga lembaga, yaitu legislatif, yudikatif dan eksekutif, sehingga kinerja setiap bagian dapat dipantau secara bersamasama.

Di luar hal ini, sebelum dilantik dan ditetapkan sebagai pemimpin, mereka telah melewati mekanisme dan peraturan yang berlaku ketika masih menjadi calon. Penyaringan dan proses verifikasi yang cukup ketat dari pihak Komisi Pemilihan Umum (KPU) bukanlah hal yang sembarangan, semua sudah diatur oleh undang-undang melalui perimbangan-pertimbangan dari berbagai macam aspek. Bahkan tidak hanya sampai disitu, setelah terpilih pun mereka melakukan sumpah jabatan ketika dilantik.Bukan suatu hal yang berlebihan peneliti rasa jika dalam hal ini dapat disepakati pendapat al-Māwardī terkait pembolehan terhadap non-Muslim untuk menduduki kursi kepemimpinan eksekutif. Dari hal ini pula dapat terlihat kearifan Islam yang universal juga sebagai agama yanga raḥmatan li al- 'Ālaminn. 


\section{Kesimpulan}

Dari beberapa pendapat dan pandangan yang dikemukakan oleh para sarjana Muslim diatas terkait masalah kepemimpinan non-Muslim, baik yang pro atau bahkan yang kontra mempunyai landasan dan dasar pemikiran masing-masing. Menurut pandangan peneliti, dengan melihat relevansi konteks modern-kontemporer sekarang ini, pendapat kelompok pertama yang secara mutlak melarang non-Muslim sebagai pemimpin akan mengalami kegusaran dalam memebrikan solusi atas kompleksitas masalah yang terus bergulir di masyarakat muslim. Sebaliknya, kelompok kontekstual seakan bisa memahami bahwa kegundahan dan mmemberi solusi yang efektif dengan cara optimis terhadap setiap problem yang dihadapinya.

Belum lagi jika dihadapkan dengan relevansi konteks Indonesia dengan kemajemukan masyarakatnya, plural dan bertumpu pada ideologi Pancasila dan UUD 1945 yang mengharuskan bekerja sama dengan cara menjalin kesatun dan persatuan dalam mencapai cita-cita kemaslahatan dan kemajuan bersama di dalam sebuah negara. Hal ini tidak lantas mengenyampingkan motifasi yang disampaikan oleh 'ulama-'ulama klasik kelompok pertama yang menolak kepemimpinan non-Muslim, untuk selalu meningkatkan keimanan dan kecintaan serta ketaatan sebagai seorang Muslim kepada Allah swt sebagai spirit dalam hidup beragama, berbangsa, dan bernegara.

Dengan tanpa mengenyampingkan seluruh pendapat para cendekiawan muslim baik yang klasik maupun kontemporer diatas, lantas sikap yang perlu diperhatikan adalah perlunya move on dari isu dan perdebatan tentang boleh atau tidaknya pemimpin non-Muslim. Sebagai muslim justru harus lebih siap dan cermat untuk menyiapkan sosok pemimpin Islam yang kompeten dan benar-benar sesuai dengan hal yang diharapkan oleh elemen masyarakat. Dengan lahirnya pemimpin Muslim yang layak, kompeten dan dapat memenuhi kriteria ini dengan sendirinya akan dapat menjadi peredamdari problematika perdebatan yang mucul belakangan ini, khususnya konteks kepemimpinan di Indonesia. 


\section{Daftar Pustaka}

Agha, Mahir Ahma. Yahud: Catatan Hitam Sejarah. Jakarta: Qisthi Press, 2011.

Aini, Noryamin. "Dasar Legitimasi Sosiologis Gagasan Perubahan Undang-Undang No. 1 Tahun 1974 Dalam Konteks Perubahan Sosial”. Jurnal Syariah Jurnal Ilmu Hukum 1, 7 (2007).

Cawidu, Harifuddin. Konsep Kufur Dalam Alquran; Suatu Kajian Teologis Dengan Pendekatan Tafsir Tematik. Jakarta: Bulan Bintang, 1991.

Esposito, John L. Islam dan Politik. Terj. Joesoef Sou'ybdari Islam and Politics. Jakarta: Bulan Bintang, 1990.

Gkasse, Cyril. Ensiklopedi Islam. Jakarta: PT Raja Grafindo Persada, 1997.

Ibn 'Arabī. Abū Bakr Muḥammad Ibn 'Abdillāh. Aḥkām al-Qur'ā'. Bairūt-Libanon: Dār al-Quṭb al-'Ilmiyyah, 1988.

Ishom, Muhammad. "Pemikiran Sayyid Quṭb dalam Referensi Gerakan Islam Politik, al Qisthas”. Jurnal Hukum dan Politik 9, 1 (2018).

al-Jauziyah. Ibn al-Qayyīm. 'Alām al-Muwaqqi'īn Rabb al- 'Ālamīn. Qāhirah: Maktabah al-Kulliyyah al-Azhāriyyah, T.t.

al-Jașāṣ. Abū Bakar Aḥmad Ibn 'Āli al-Rāzī. Aḥkām al-Qur'ān. Qāḥirah: Syirkah alMaktabah wa Maṭba'ah Abd al-Raḥmān Muḥammad, T.t.

Khalīlupethes. Șafwāt Musțafā'. al-Imām Abū Bakr al-Rāzì al-Jaṣāṣ wa Manḥājuhu fì al-Tafsīr. Qāhirah: Dār al-Salām, T.t.

al-Māwardī. Abū al-Ḥasān. al-Ahkā̄m al-Sulțānīyah wa al-Wilāyāt al-Dīnīyah. Bairūt: Dār al-Fikr, 1996.

Mujar, Syarif Ibnu. Presiden Non Muslim di Negara Muslim: Tinjauan dari Perspektif Politik Islam dan Revolusinya dalam Konteks Indonesia Jakarta: Pustaka Sinar Harapan, 2006.

al-Na'̄̄m, 'Abdullāh Aḥmad. Toward an Islamic Reformation: Civil Liberties Human Rights and International Law. Terj. Ahmad Suaedy dan Amiruddin Arrany dari buku Dekonstruksi Syariah. Yogyakarta : LKIS, 1994.

Qodir, Zuly. Pembaharuan Pemikiran Islam. Yogyakarta: Pustaka Pelajar, 2006.

Quṭb, Sayyid. F̌̄ Zilāl al-Qur'ān. Bairūt-Libanon: Dār Iḥyā al-Turāì al-'Arabī, 1967.

Shihab, M. Quraish. M. Quraish Shihab Menjawab 1001 Soal Keislaman Yang Patut Anda Ketahui. Jakarta: Lentera Hati, 2008. 
- Wawasan Al-Quran, (Tafsir Tematik atas Berbagai Persoalan Umat). Bandung: PT Mizan Pustaka, 2013.

Syadzali, Munawir. Islam: Realitas Baru dan Orientasi Masa Depan Bangsa Jakarta: UI Press, 1993.

Umar, Nasaruddin. Deradikalisasi Pemahaman Alquran dan Hadis. Jakarta: PT Elex Media Komputindo, 2014. 